\title{
An in Vitro Animal Model for the Study of Cereal Components Toxic in Celiac Disease
}

\author{
S. AURICCHIO, M. CARDELLI, G. DE RITIS, M. DE VINCENZI, F. LATTE, AND V. SILANO \\ Clinica Pediatrica, II Facoltà di Medicina e Chirurgia, Naples, Gruppo di ricerca del Consiglio Nazionale delle \\ Ricerche, sulla Fisiologia e Patologia dell'Apparato Digerente [S.A., G.d.R., F.L.] and Department of \\ Comparative Toxicology and Ecotoxicology, Istituto Superiore di Sanitá, Roma, Italy [M.C., M.D.V., V.S.], \\ Programme of Preventive Medicine, Project of Perinatal Pathologies and Their Consequences, Consiglio
} Nazionale delle Ricerche, Rome, Italy

\begin{abstract}
Peptic-tryptic-Cotazym (PTC) digests were obtained, simulating in vivo protein digestion, from rice, maize, rye, oats, barley, and sorghum prolamines and tested on small intestine cultures from rat fetus. The PTC digests of the prolamine fractions from rice and maize, even when tested at a concentration as high as $0.5 \mathrm{mg} / \mathrm{ml}$, did not affect in vitro differentiation and maturation of fetal rat jejunum that took place in vitro in a way comparable to what happens in vivo. On the contrary, the PTC digests of prolamines from rye, oats, barley, and sorghum were very active in slowing down in vitro development of fetal rat intestine. These results further strengthen earlier findings and all together show that there is a strong correlation between toxicity results of cereal and/or cereal components assessed with clinical trials or in vitro systems based on bioptic specimens of intestinal mucosa from celiac patients and with the culture of rat fetal intestine. Therefore, the rat fetal intestine culture is considered to be an adequate model for screening and investigating cereal peptides which are toxic for the celiac small intestinal mucosa. (Pediatr Res 18:1372-1378, 1984)
\end{abstract}

\section{Abbreviations}

PTC, peptic-tryptic-cotazym

GP, gliadin peptides

Celiac disease is an enteropathy occurring in genetically predisposed individuals (about $0.5 / 1000$ of the general population) when wheat is a component of the diet. Under such circumstances, diarrhea and several malabsorption symptoms are observed in association with intestinal mucosa atrophy. Soon after the discovery that wheat is the environmental factor triggering the appearance of malabsorption symptoms, it was demonstrated that wheat toxicity resulted from the gliadin protein fraction and that the other wheat protein fractions, i.e. albumins, globulins, and glutenins, were harmless $(6,64,65,67)$. Later on it was shown $(27,28)$ that the ingestion of peptide mixtures obtained from wheat gluten after in vitro sequential digestion with proteolytic enzymes also induces the typical symptoms in patients affected by celiac disease. Moreover, clinical trials have shown

Received July 29, 1983: February 7, 1984.

Address correspondence to Salvatore Auricchio, Clinica Pediatrica, II Facoltà di Medicina e Chirugia, Via Sergio Pansini 5, 80131 Naples, Italy.

This paper is dedicated by the authors to Professor Francesco Pocchiari on the occasion of his 60 th birthday. that, in addition to wheat, rye, barley, and probably oats also have toxicity $(7,41)$, whereas rice and maize are considered nontoxic and are usually used as wheat substitutes in the diet of celiac patients. It is presumed, but not demonstrated, that toxicity of cereals other than wheat is associated with prolamine fractions equivalent to gliadins in the grain of these other species.

The detection and characterization of cereal components that are toxic in celiac disease are very difficult because no animal models exist for this disease. Falchuk et al. $(19,20)$ have proposed the organ culture of human small intestinal biopsies as an in vitro model of celiac disease. Jejunal specimens obtained from patients with active enteropathy show morphological and biochemical improvement when cultured in a gliadin-free medium. No improvement occurs when the tissue is cultured in the presence of gliadin peptides. Several other authors $(23,35,36$, 40) have confirmed these findings, although Haury et al. (30) were not able to show a cytotoxic effect of various gliadin preparations on organ culture of small intestinal mucosa from celiac children.

Jejunal mucosa from celiac patients in remission and from normal subjects is not affected by the presence of gliadin in the culture medium. These findings led Falchuk et al. $(21,22)$ to suggest that gliadin must first initiate a set of events in vivo, possibly related to the immune system, before the cytotoxic effect on enterocytes can be displayed in vitro. Cultured intestinal epithelial tissues from celiac patients have been tested also by Jos et al. (36-38) who showed that peptides derived from purified gliadin fractions including $\alpha_{-}^{-}, \beta-, \gamma_{-}^{-}$, and $\omega$-gliadins were toxic in celiac disease. These results were consistent with those by Hekkens et al. (32) who demonstrated that an $\alpha$-gliadin fraction, coded A-gliadin $(10,49)$, was capable of producing changes in epithelial tissue characteristic of celiac disease when instilled directly into the small intestine of celiac patients and with those by Falchuk et al. (19) showing that this fraction had adverse effects on biopsied intestinal epithelium. Fluge and co-workers (24-26) have developed a morphological, morphometric, and biochemical assessment of human duodenal biopsies from celiac patients maintained in organ culture and have tested with this in vitro system several gliadin fractions including $\alpha$-gliadin and Frazer's fraction III and subfractions. Biopsies from patients with untreated celiac disease were susceptible to gliadin fractions, which provoked disorganization of crypt architecture, reduced height, and irregularities of enterocytes and crypt cells, together with detrition of surface epithelial cells and even tissue necrosis. Remission mucosas and biopsies from nonceliac controls showed no signs of impairment after gliadin exposure in vitro. A quantitative assessment of histological changes during organ culture of small bowel mucosa has also been performed by Howdle et al. (34) who reported, however, a significant decrease of entero- 
cyte height in mucosa specimens, cultured in the presence of gliadin peptides, from treated celiac patients.

Although very useful, in vitro systems based on bioptic specimens of intestinal mucosa from celiac patients cannot be used widely for research purposes for ethical reasons; these specimens, in fact, are only available for diagnosis. Moreover, limited available specimens obviously cannot be standardized and may provide poorly reproducible results.

To overcome these limitations, we undertook a research program to evaluate whether the in vitro developing intestine from rat fetus was a suitable model for the study of peptides toxic in celiac disease. We considered this possibility because of the enterocyte changes seen in celiac disease (e.g. increased cell turnover, increased mitotic index and lengthening of crypts) suggestive of the emergence of less differentiated cells on the villus (68). We considered that the easiest way of exposing immature enterocytes throughout the differentiation cycle to wheat peptides would have been to let jejunal segments from 17day-old rat fetuses (with no villi and with undifferentiated cuboidal stratified epithelia lining the jejunum) to differentiate and mature in vitro in a culture medium containing test peptides. It was well known, at that time, that morphological maturation of fetal intestinal mucosa takes place under adequate in vitro conditions in a way comparable to what happens in vivo (16). First we demonstrated (17) that a PTC digest of hexaploid (bread) wheat gliadin, obtained by simulating in vivo protein digestion, was very active in inhibiting in vitro development and morphogenesis of small intestine from 17- and 18-day-old rat fetuses, whereas it had no effect on the culture of jejunum from 21-dayold fetuses or from newborn rat.

As Cornell and Townley (13) reported the fractionation of this PTC digest into 10 major peptidic fractions and showed the fraction eluted with $0.02 \mathrm{M}$ phosphate buffer (coded as fraction 9) to be extremely toxic for cultured mucosa of patients with active celiac disease, we also tested the effect of this fraction on rat fetal intestine; fraction 9 was much more active than the total gliadin digest in inhibiting differentiation of this fetal tissue (17). Then PTC digests were obtained from albumin, globulin, gliadin, and glutenin preparations from hexaploid (bread) wheat as well as from diploid (monococcum) and tetraploid (durum) wheat gliadins. The digest from bread wheat gliadins reversibly inhibited in vitro development and morphogenesis of small intestine from 17-day-old rat fetuses, whereas all the other digests (obtained both from nongliadin fractions and from gliadins from other wheat species) were inactive (4). The PTC digest from bread wheat gliadins was also able to prevent recovery of and damage to the in vitro cultured small intestinal mucosa from patients with active celiac disease. The PTC digest from durum wheat gliadins caused a much less adverse effect on this human pathological tissue culture system (4). Both PTC digests did not cause any detectable effect on normal human small intestinal mucosa.

This paper deals with investigations on the effects of prolamine-derived peptides from rice, maize, rye, oats, barley, and sorghum on small intestine cultures from rat fetus. In view of the very different levels of prolamine fractions in the kernels of different cereals (e.g. as an average, oats contains $4 \mathrm{~g}$ prolamine/ $100 \mathrm{~g}$ of seed protein; wheat, 45 ; maize, 64 ; barley, 41 ; rice, 2 ; rye, 40 ; and sorghum, 55) (62), the purpose of these investigations was 2 -fold. From one side, we intended to verify whether toxicity in celiac disease of rye, oats, and barley depends, as it is generally assumed but not proven, on the presence of prolamine-derived peptides with a biological activity similar to that exhibited by bread wheat gliadin peptides. From the other side, we intended to check whether the absence of toxicity of rice in celiac disease was due to the very low content of total prolamine in this cereal or rather to absence of toxicity of rice prolamine, as compared to bread wheat gliadin. Moreover, this paper contains an extensive critical review of all available data relevant to assess the value of the in vitro developing rat fetus jejunum for detecting and characterizing cereal components toxic in celiac disease.

\section{MATERIALS AND METHODS}

Pure rice (Oryza sativa var. Roma), maize (Zea mays var. B73), rye (Secale cereale var. $\left.500-2^{\circ} \mathrm{G}\right)$, barley (Hordeum vulgare var. Arma), sorghum (Sorghum vulgare var. NK120), and oats (Avena sativa var. Astra) were kindly supplied by the Istituto Sperimentale per la Cerealicoltura in Rome.

Prolamine fractions from the above cereals were obtained with an experimental procedure identical to that described by Auricchio et al. (4) and summarized in Figure 1. Peptic-trypticCotazym digests of the purified prolamine fractions were prepared following the three-step procedure of Bronstein et al. (11) as reported by de Ritis et al. (17). At the end of the whole procedure, PTC digests were submitted to ultrafiltration in an Amicon 400-mm cell equipped with a UM 2 Amicon membrane to remove compounds with molecular weight lower than 2,000 and to obtain a peptide fraction with molecular weight in the range $2,000-10,000$.

For the in vitro culture of fetal jejunum, pregnant Wistar rats were anesthetized with ether and 17-day-old fetuses were removed at laparatomy. Fetal jejunum segments were isolated and cultured in vitro for $48 \mathrm{~h}$ in a serum-free medium according to the method described by de Ritis et al. (16). Jejunal segments from the same fetus were cultured in the absence and in the presence of tested peptides. All the peptide mixtures were sterilized before addition to the incubation medium by filtration through $0.22-\mu \mathrm{m}$ Millipore filters. Differentiation of the fetal rat jejunum was followed morphologically by light microscopy as reported by de Ritis et al. (17).

\section{RESULTS}

Before culture, jejunal mucosa from 50 17-day-old rat fetuses did not show any villus, and only undifferentiated cuboidal stratified epithelia lining the lumen were present; very rudimentary villi with monostratified epithelial cells were observed in only four fetuses (Table 1; Fig. 2A). No goblet cells could be detected in all the uncultured fetuses.

After $48 \mathrm{~h}$ of in vitro culture in the absence of peptides (Table 1; Fig. $2 B$ ), well formed villi were present in 44 fetal jejunum segments and rudimentary villi were observed in jejunal segments from seven other fetuses. In 50 fetuses, the epithelial lining consisted exclusively of simple columnar epithelium and in 23 cases goblet cells were detected. Patchy slight degenerative changes were observed only in a few cultured jejunal from 10 fetuses. These findings confirm previous results by de Ritis et al. (17) and Auricchio et al. (4) showing that differentiation and maturation of small intestinal mucosa from rat fetuses takes place in vitro in a way comparable to in vivo differentiation.

The peptic-tryptic-Cotazym digests of the prolamine fractions from rice and maize did not affect in vitro differentiation of fetal rat jejunum, even when tested at a concentration as high as 0.5 $\mathrm{mg} / \mathrm{ml}$ (Table 1. Fig. 2C). After 48 -h culture in the presence of rice prolamine peptides, villi were present in all 22 cases: they were rudimentary in only five cases and well formed in all other cultures, with a differentiated columnar epithelium in all cases except two and goblet cells were present in three cases. Similar results were obtained with the maize prolamine peptides; villi were absent only in three cases, rudimentary in three, and well developed in 13 cases with differentiated columnar epithelium in 15 and goblet cells in two cultured fetal jejunum of 19 total (Table 1).

In contrast to what was observed with rice and maize, the PTC digest of prolamines from rye, oats, barley, and sorghum were very active in slowing down in vitro development of fetal rat intestine and in increasing occurrence and severity of degenerative changes (Table 1; Fig. $2 D$ ). Such effects were clearly observed also at the lowest peptide concentration tested $(0.1 \mathrm{mg}$ of peptides $/ \mathrm{ml}$ of culture medium). After 48 -h culture in the presence of rye, oat, barley, and sorghum prolamine peptides, well developed villi were absent in the most tested cultures. Rudimentary 


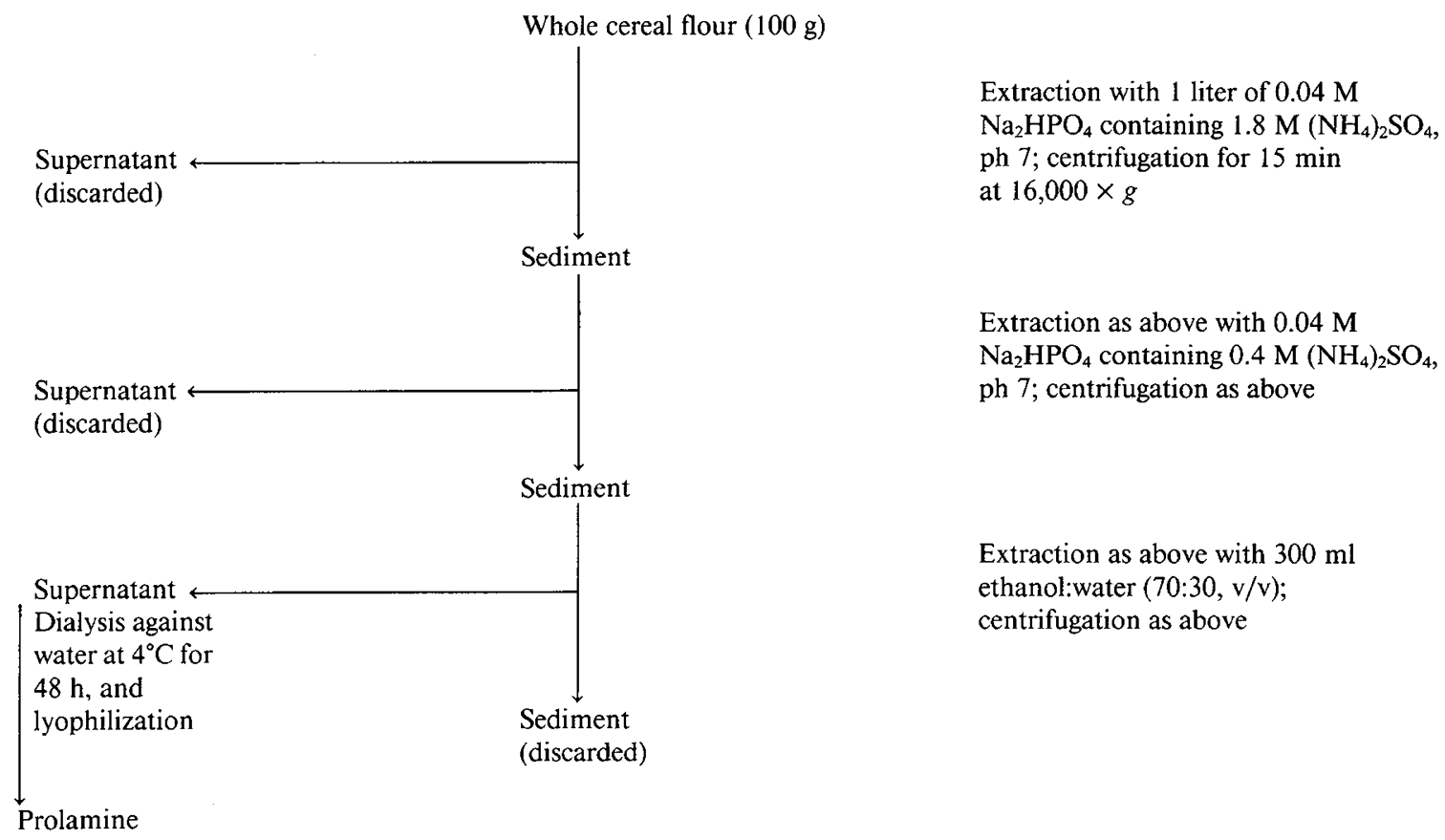

Fig. 1. Extraction of prolamine fractions from whole cereal flour.

Table 1. Morphologic features in maturation of rat fetal jejunum cultured in vitro in the presence of peptides from different cereals

\begin{tabular}{|c|c|c|c|c|c|c|c|c|c|}
\hline \multirow[b]{3}{*}{ Sample* } & \multicolumn{3}{|c|}{ Villi } & \multicolumn{3}{|c|}{ Epithelium } & \multirow{3}{*}{$\begin{array}{c}\text { Goblet } \\
\text { Cells }\end{array}$} & \multirow{3}{*}{\multicolumn{2}{|c|}{$\begin{array}{c}\text { Degenerative } \\
\text { changes } \dagger\end{array}$}} \\
\hline & \multirow[b]{2}{*}{ Absent } & \multirow[b]{2}{*}{ Rudimentary } & \multirow[b]{2}{*}{ Present } & \multirow[b]{2}{*}{ Stratified } & \multicolumn{2}{|c|}{ Monostratified } & & & \\
\hline & & & & & Cuboidal & Columnar & & & \\
\hline \multicolumn{10}{|l|}{ Uncultered } \\
\hline 17-day fetuses (54) & 50 & 4 & & 50 & 3 & 1 & & \pm & ++ \\
\hline \multicolumn{10}{|l|}{ After 48 -h culture } \\
\hline Without peptides (54) & 3 & 7 & 44 & & 4 & 50 & 23 & 10 & \\
\hline \multicolumn{10}{|l|}{ PTC rice prolamine } \\
\hline $0.1 \mathrm{mg} / \mathrm{ml}(10)$ & & 2 & 8 & & & 10 & 2 & 1 & \\
\hline $0.5 \mathrm{mg} / \mathrm{ml}(12)$ & & 3 & 9 & & 2 & 10 & 1 & 3 & \\
\hline \multicolumn{10}{|l|}{ PTC maize prolamine } \\
\hline $0.1 \mathrm{mg} / \mathrm{ml}(9)$ & 1 & 2 & 6 & & 2 & 7 & 2 & 2 & \\
\hline $0.5 \mathrm{mg} / \mathrm{ml}(10)$ & 2 & 1 & 7 & & 2 & 8 & & 4 & \\
\hline \multicolumn{10}{|l|}{ PTC rye prolamine } \\
\hline $0.1 \mathrm{mg} / \mathrm{ml}(10)$ & 9 & 1 & & & 3 & 7 & & 4 & \\
\hline $0.5 \mathrm{mg} / \mathrm{ml}(10)$ & 10 & & & 1 & 3 & 6 & & 6 & \\
\hline \multicolumn{10}{|l|}{ PTC oat prolamine } \\
\hline $0.1 \mathrm{mg} / \mathrm{ml}(8)$ & 6 & 2 & & & 3 & 5 & & 5 & \\
\hline $0.5 \mathrm{mg} / \mathrm{ml}(6)$ & 5 & 1 & & & 3 & 3 & & 4 & \\
\hline \multicolumn{10}{|l|}{ PTC barley prolamine } \\
\hline $0.1 \mathrm{mg} / \mathrm{ml}(12)$ & 8 & 3 & 1 & 1 & 3 & 8 & & 5 & \\
\hline $0.5 \mathrm{mg} / \mathrm{ml}(10)$ & 8 & 2 & & & 4 & 6 & & 4 & \\
\hline \multicolumn{10}{|l|}{ PTC sorghum prolamine } \\
\hline $0.1 \mathrm{mg} / \mathrm{ml}(8)$ & 6 & 2 & & & 2 & 6 & & 2 & \\
\hline $0.5 \mathrm{mg} / \mathrm{ml}(6)$ & 6 & & & & 2 & 4 & & 1 & 1 \\
\hline
\end{tabular}

* Number of fetuses examined or of fetal jejuna cultured in parentheses.

$\dagger \pm$ indicates slight degenerative changes; ++ indicates large necrotic areas.

villi were present in only one test culture in the presence of rye peptides in three cultures in the presence of oat peptides, in five cultures in the presence of barley peptides, and in two cultures in the presence of sorghum peptides. Columnar epithelium was observed in 13 culture segments in the presence of rye prolamine peptides, in eight segments in the presence of oat peptides, in 14 segments in the presence of barley peptides, and in 10 cultured segments in the presence of sorghum prolamine peptides. Goblet cells were absent in all the treated cultures. Last, in one culture in the presence of sorghum prolamine peptides, extensive degenerative changes with some areas of necrosis were observed.

\section{DISCUSSION}

Toxicity in celiac disease of cereals other than wheat. If the results described in Table 1 are compared with those previously reported by Auricchio et al. (4) for PTC digests of bread wheat gliadin, it is quite clear that no significant difference among 

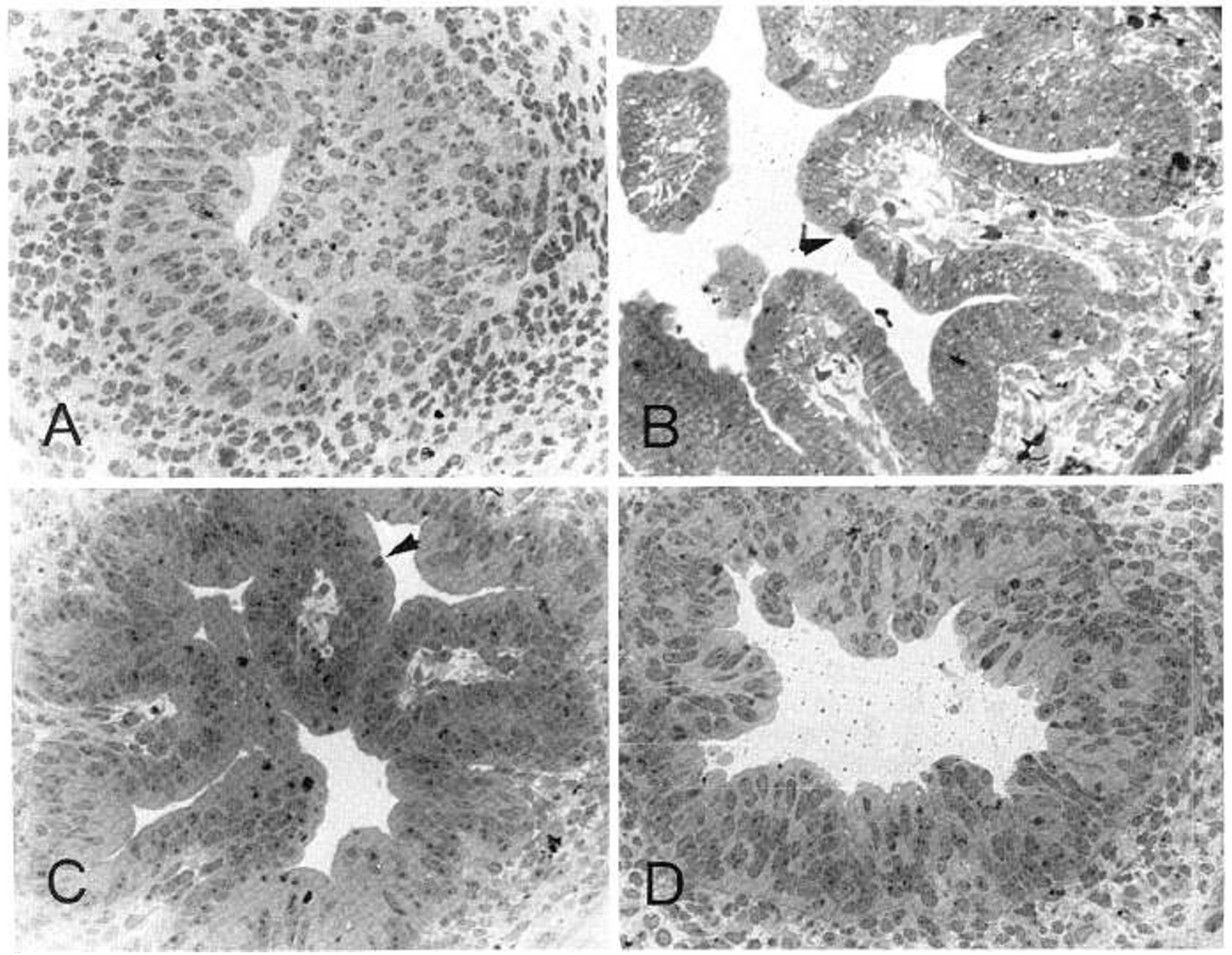

Fig. 2. Effect of peptic-tryptic-Cotazym digest of prolamines from rice and barley on in vitro development and morphogenesis of jejunum from 17-day-old-rat fetus. $A$, jejunal mucosa before culture. The mucosal epithelium consists of stratified undifferentiated cells and no villi are present. $B$, jejunal mucosa after 48 -h culture; $C$, jejunal mucosa after 48 -h culture in the presence of PTC prolamine digest $(0.5 \mathrm{mg} / \mathrm{ml}) \mathrm{from}$ rice. Well developed villi are present which are lined by a single layer of relatively differentiated columnar epithelial cells. Some goblet cells are also present (arrow). D, jejunal mucosa after 48 -h culture in the presence of PTC prolamine digest from barley $(0.5 \mathrm{mg} / \mathrm{ml})$. Villi are absent from the mucosal surface which is lined by cuboidal and columnar epithelial cells. Degenerative changes are evident and no goblet cells could be identified.

toxicities of PTC digests of rye, oats, barley, sorghum, and bread wheat prolamines for culture of rat fetal intestine could be detected under our experimental conditions. These findings, therefore, strongly support current views that toxicity of the above-mentioned cereals is associated with the prolamine fractions. Moreover, the doubtful toxicity of oats in celiac disease likely depends on the much lower content of prolamine in this cereal (see introduction for quantitative figures). On the other hand, our findings suggest that the lack of toxicity of rice and maize in celiac disease is not dependent on a different content of prolamine in the kernel but mainly on the absence of the toxic peptide sequences(s) in their prolamines. Interestingly enough, such constitutive differences among prolamine fractions not only exist among different cereal genera, but also among different wheat species, as it was clearly shown for total gliadin fractions from bread (hexaploid), durum (tetraploid), and monococcum (diploid) wheats by Auricchio et al. (4) and for purified $\alpha$-gliadin fractions from bread and durum wheats (S. Auricchio, M. Cardelli, G. de Ritis, M. De Vincenzi, and V. Silano, in preparation).

Significance of rat fetal intestine culture for testing cereal components toxic in celiac disease. As shown in Tables 2 and 3 , there is a strong correlation between toxicity results of cereal and/or cereal components assessed with clinical trials or in vitro system based on bioptic specimens of intestinal mucosa from celiac patients and with the culture of rat fetal intestine. As a matter of fact, until now, no peptide or protein fraction known to be toxic in celiac disease has been shown to be harmless for the rat fetal intestine undergoing maturation and differentiation in vitro. Similarly, a number of peptide or protein fractions that are known to be harmless for celiac patients have also been proven to be so for the rat fetal intestine. All together these results suggest that the in vitro developing fetal rat intestine is an adequate model for screening of cereal peptides potentially toxic for celiac mucosa.

It should be noted that, if properly used, this in vitro system is not prone to false positive results. In fact, the inhibitory effect of intestinal morphogenesis relevant for celiac disease should be reversible (that is the intestinal mucosa should undergo a normal morphogenesis if transferred to a fresh culture medium) and transient (that is no adverse effect should be detectable on in vitro cultured jejunal segments from 21-day-old rat fetus). Moreover, if properly digested proteins and intestinal specimens sampled at the proper developmental stage are tested, the possibility 
Table 2. Cereal and cereal components found to be toxic for celiac patients in vivo and/or in cultured intestinal systems

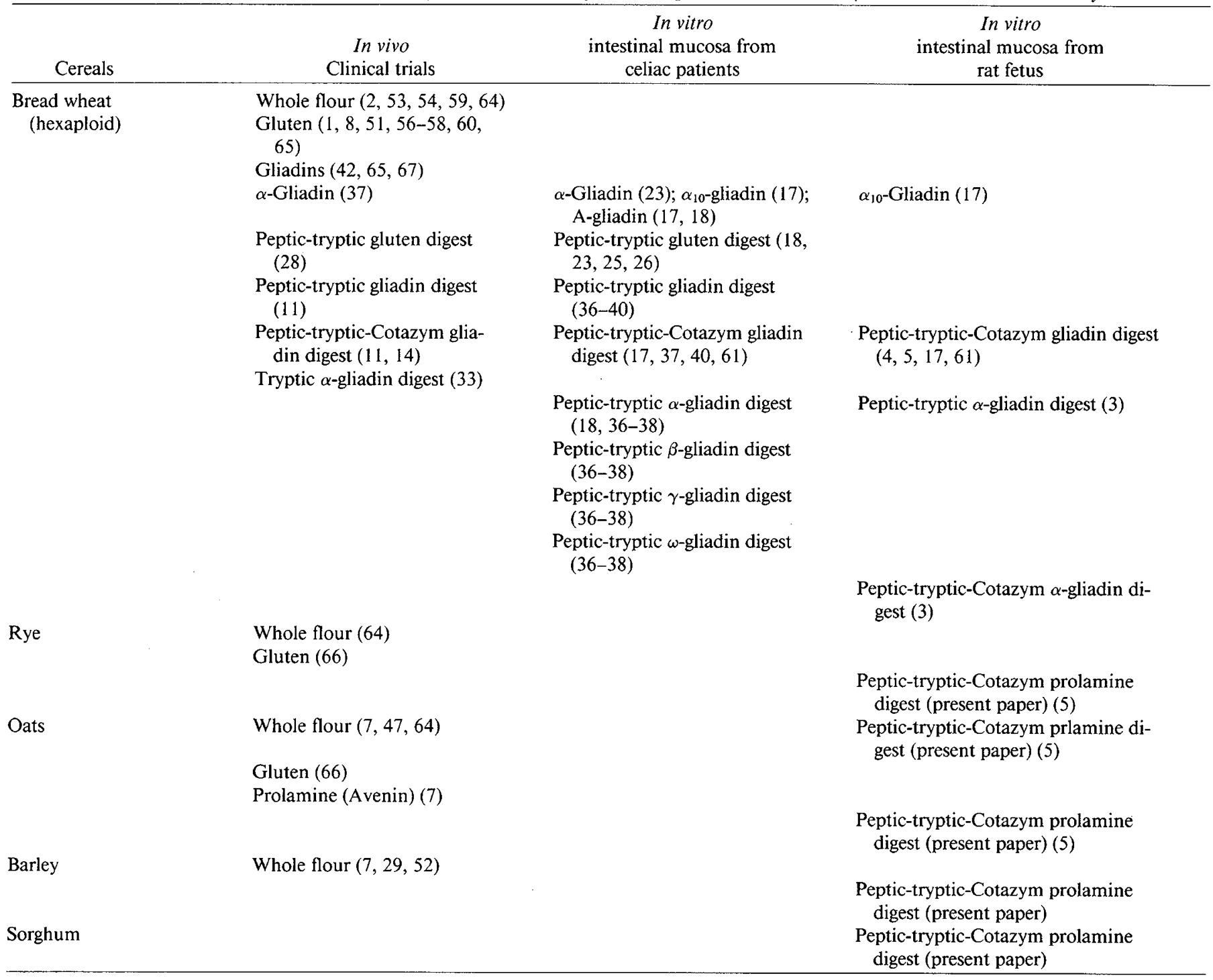

Table 3. Cereal and cereal components found to be not toxic for celiac patients in vivo and/or in cultured intestinal systems

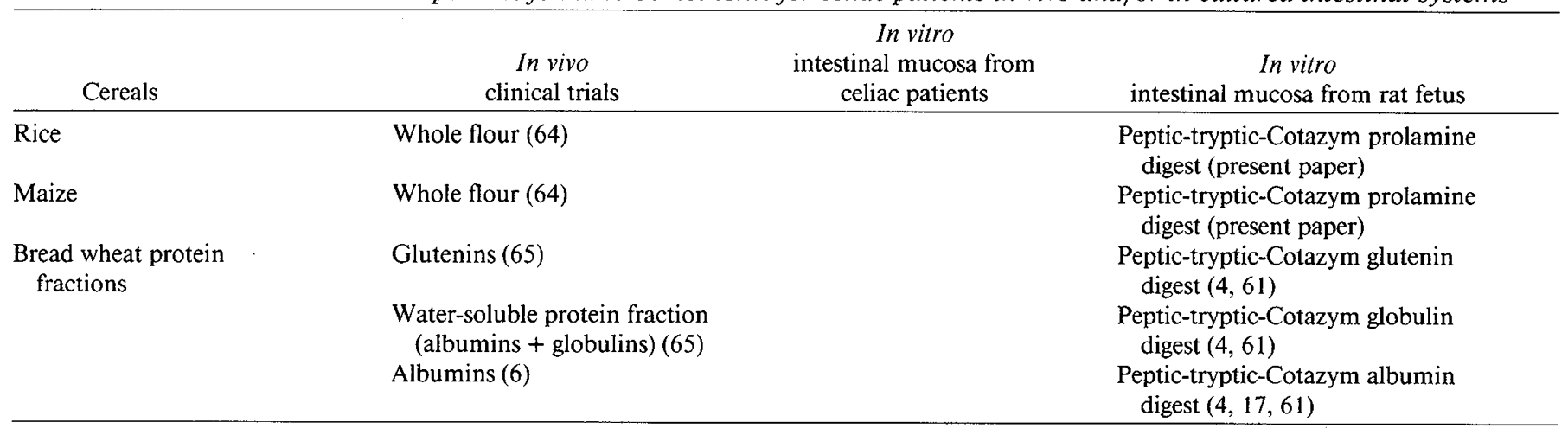

of false negative results, if any, is also very limited. This is not the case when testing whole gliadin fractions; in fact, undigested A-gliadin was found to be nontoxic in this in vitro system (17), whereas predigested A-gliadin was toxic (4). Clearly, testing of samples insoluble in the incubation medium can lead to false negative results and only predigested proteins should be tested in this system.

Significance of the rat fetal intestine culture as a model to investigate pathogenetic mechanisms of celiac disease. The effec- tiveness of the in vitro animal model discussed in this paper in detecting cereal components toxic in celiac disease may have some implications in terms of pathogenetic mechanisms of celiac disease.

We have demonstrated that gliadin peptides are very active in inhibiting in vitro development and morphogenesis of small intestine from 17- and 18-day-old rat fetus, whereas they have no effect on the culture of the differentiated jejunum from 21 day-old fetuses or from newborn rats (17). This may suggest that 
one of the mechanisms likely underlying the mucosal damage in gluten-dependent enteropathy is a direct cytotoxic action of some cereal peptides on immature enterocytes or enterocytes characterized by immature-like cell membrane components. The following observations also suggest that GP are able to induce in vitro adverse biological effects on relatively undifferentiated cell and tissue systems:

(i) GP are nontoxic for in vitro cultured histologically normal celiac small intestinal mucosa in remission, whereas they are toxic for the flat celiac mucosa, lined by immature enterocytes $(18,25)$. (ii) GP have lectin-like properties; they bind to brush border glycoproteins of immature crypt cells of rat intestine and much less to brush border glycoproteins from enterocytes of the mature villous zone (44). (iii) GP are able to activate cell membrane adenylate cyclase in the flat celiac mucosa and not in the histologically normal mucosa of patients in remission (15). (iv) Last, GP reduce in vitro viability of human embryo and tumor cell lines, whereas they are inactive on adult human cells (50).

According to Weiser and Douglas (68), a defect of the cell surface membrane of the celiac enterocyte allows gliadin to act as a lectin and this reaction initiates cell toxicity. In our opinion, this could be due either to the presence on enterocytes of celiac patients of specific receptors acting as a target of cereal peptides or to a regression in celiac disease towards immature enterocyte determinants, which are susceptible to interaction with toxic cereal peptides. With reference to the latter hypothesis, it should be pointed out that the regression of the intestinal mucosa towards immature stages could possibly be induced by other primary causes acting in celiac disease. One of such primary causes could be the well known immunological hyperresponsiveness to some cereal proteins occurring in celiac disease. If this immunological reaction is a part of the mechanisms underlying the appearance of the disease, we may speculate, according to Ströber (63), that this happens because the small intestinal mucosa becomes the target of this immunological reaction, in the presence of certain cereal antigens. The turnover of enterocytes could therefore be accelerated with the emergence on the villi of immature epithelial cells which are susceptible to the toxic action of cereal peptides.

Significance of the rat fetal intestine culture for the study of gluten-dependent enteropathies other than celiac disease. Several such enteropathies have been described in the literature. Bayless and Swanson (9) reported that patients with tropical sprue reacted to a gluten-free diet with a decreased steatorrhea and with an improvement in the jejunal lesions. Hedberg et al. (31) described a postgastrectomy steatorrhea that was improved by a gluten-free diet. Levine et al. (45) found that in some subjects convalescing from Laennec's cirrhosis, tubercolosis, or viral hepatitis a significant increase in fecal fat excretion resulted upon addition of $10-150 \mathrm{~g}$ gluten daily to the diet; no effect was observed with normal individuals. Rudman et al. (55) demonstrated that patients with regional enteritis suffer from gastrointestinal bleeding, increased steatorrhea, fever, diarrhea, and abdominal discomfort due to inclusion of gluten in the diet. Moreover, temporary gluten intolerance (46) as well as gluten-sensitive diarrhea without evidence of celiac disease (12) and nonceliac gluten intolerance in infancy (48) have also been described.

We speculate that, at least in some of these pathological conditions, basic physiological alterations, although different from those observed in celiac disease for being secondary (nongenetically determined) and transient (as they depend on other primary disease), may lead to an acceleration of enterocyte turnover similar to that observed in celiac disease. Therefore, the mechanisms through which gluten peptides induce toxic effects could be basically the same in secondary and primary glutendependent enteropathies and consist of a lectin-like interaction of gluten peptides with immature enterocytes.

Acknowledgment. We are very grateful to Mr. Francesco Paparo for the technical assistance.

\section{REFERENCES}

1. Alvey C. Anderson CM, Freeman M 1957 Wheat gluten and coeliac disease Arch Dis Child 32:434

2. Anderson CM, Frazer AC, French JM, Gerrard WJ, Sammons HG, Smellie JM 1952 Coeliac disease. Gastrointestinal studies and the effect of dietary wheat flour. Lancet 1:836

3. Deleted in proof

4. Auricchio S, de Ritis G, De Vincenzi M, Occorsio P, Silano V 1982 Effects of gliadin peptides prepared from hexaploid and tetraploid wheat on cultures of intestine from rat fetuses and coeliac children. Pediatr Res 16:1004

5. Auricchio S, de Ritis G, De Vincenzi M, Silano V 1979 Toxicity of cereal protein-derived peptides for in vitro developing intestine from rat fetus. J Am Oil Chemists Soc 56:168

6. Auricchio S, De Vizia B, Carta De Angelis L, Silano V 1974 Alpha-amylase protein inhibitors from wheat in coeliac disease. Lancet 19:98

7. Baker PG, Read AE 1976 Oats and barley toxicity in coeliac patients. Postgrad Med J 52:264

8. Bayless TM, Rubin SE. Topping TM. Hardley JH, Hendrix TR 1970 Morphological and functional effects of gluten feeding on jejunal mucosa in coeliac disease. In: Booth CC, Dowling RH (eds) Coeliac Disease. Churchill Livingstone, London, $\mathrm{p} 76$

9. Bayless TM, Swanson VL 1964 Comparison of tropical sprue and adult coeliac disease (non tropical sprue). Gastroenterology 46:731

10. Bernardin JE. Kasarda DD, Mecham DR 1967 Preparation and characterization of $\alpha$-gliadin. J Biol Chem 242:445

11. Bronstein HD, Haeffner LJ, Kowlessar OD 1966 Enzymatic digestion of gliadin: the effect of the resultant peptides in adult coeliac disease. Clin Chim Acta 14:141

12. Cooper BT, Holmes GKT, Ferguson R, Thompson RA, Cooke WT 1978 Gluten sensitive diarrhea without evidence in coeliac disease. In: McNicholl B, McCarthy CF, Fottrell PF (eds) Perspectives in Coeliac Disease. MTP Press Limited, Lancaster, p 500.

13. Cornell HJ. Towniey RRW 1973 Investigation of possible intestinal peptidase deficiency in coeliac disease. Clin Chim Acta 43:113

14. Cornell HJ, Townley RRW 1974 The toxicity of certain cereal proteins in coeliac disease. Gut 15:862

15. de Ritis G, Beguinot L, Macchia V, Bernardin JE, Kasarda DD, Auricchio S 1982 Activation of small intestinal mucosa adenylate cyclase by gliadin peptides in children with coeliac disease. Pediatr Res 16:1039

16. de Ritis G. Falchuk ZM, Trier JS 1975 Differentiation and maturation of cultured fetal rat jejunum. Dev Biol 45:304

17. de Ritis G, Occorsio P, Auricchio S, Gramenzi F, Morisi G, Silano V 1979 Toxicity of wheat flour proteins and protein-derived peptides for in vitro developing intestine from rat fetus. Pediatr Res 13:1255

18. Falchuk ZM. Gebhard RL. Ströber W 1974 The pathogenesis of gluten sensitive enteropathy (coeliac sprue): organ culture studies. In: Hekkens WTJM, Pena MD (eds) Coeliac Disease. Stenfert Kroese, Leiden, p 107

19. Falchuk ZM, Gebhard RL, Sessoms C. Ströber W 1974 An in vitro model of gluten-sensitive enteropathy. J Clin Invest 53:487

20. Falchuk ZM, Katz AJ 1978 Organ culture model of gluten sensitive enteropathy. In: McNicholl B. McCarthy CF. Fottrell PF (eds) Perspectives in Coeliac Disease. MTP Press Limited, Lancaster, p 65

21. Falchuk ZM, Ströber W 1974 Gluten-sensitive enteropathy. Synthesis of antigliadin antibody in vitro. Gut 15:947

22. Falchuk ZM, Ströber W 1972 Increased jejunal immunoglobulin synthesis in patients with non-tropical sprue as measured by a solid phase immunoabsorption technique. J Lab Clin Med 79:1004

23. Fluge $\mathrm{G}$. Aksnes L 1978 in vitro assessment of gluten toxicity by organ culture of human duodenal mucosa. In: McNicholl B, McCarthy CF, Fottrell PF (eds) Perspectives in Coeliac Disease. MTP Press Limited, Lancaster, p 91

24. Fluge G, Aksnes L 1981 Labelling indices after ${ }^{3} \mathrm{H}$-thymidine incorporation during organ culture of duodenal mucosa in coeliac disease. Scand J Gastroenterol 16:921

25. Fluge G, Aksnes L 1981 Morphological and morphometric assessment of human duodenal biopsies maintained in organ culture. Scand J Gastroenterol 16:555

26. Fluge G. Andersen KJ, Aksnes L. Thunold K 1982 Brush border and lysosomal marker enzyme profiles in duodenal mucosa coeliac patients before and after organ culture. Scand J Gastroenterol 17:465

27. Frazer AC 1956 Discussion on some problems of steatorrhea and adult coeliac disease. Proc R Soc Med 49:1009

28. Frazer AC, Fletcher RF, Ross CAC. Shaw B, Sammons HG, Schneider R 1959 Gluten-induced enteropathy. The effect of partially digested gluten. Lancet $2: 252$

29. Hansted C 1956 Effects of cereals in coeliac disease. In: 8th International Congress of Pediatrics Exhibition. Copenhagen, $\mathrm{p} 137$

30. Haury HP, Kedinger M. Haffen K, Gaze H, Hadorn B, Hekkens WTJM 1978 Organ culture of small intestinal mucosa from coeliac children: absence of cytotoxicity of various gluten preparations. In: McNicholl B, McCarthy CF Fottrell PF (eds) Perspectives in Coeliac Disease. MTP Press Limited, Lancaster, p 101.

31. Hedberg CA. Melnyk CS, Johnson CF 1966 Gluten enteropathy appearing after gastric surgery. Gastroenterology 50:796

32. Hekkens WTJM, Haex AJC. Willighagen RGI 1970 Some aspects of gliadin fractionation and testing by a hystochemical method. In: Booth CC, Dowling $\mathrm{RH}$ (eds) Coeliac Disease. Churchill Livingstone, London, $\mathrm{p} 11$

33. Hekkens WTJM, Van den Arsen CJ, Gilliams JP, Lems-Van Kan P, Bouma- 
Frolich G 1974 Gliadin structure and degradation. In: Hekkens WTJM, Pena AS (eds) Coeliac Disease. Stenfert Kroese, Leiden, p 107

34. Howdle PD, Corazza GR, Bullen AW, Losowsky MS 1981 Gluten sensitivity of small intestinal mucosa in vitro: quantitative assessment of histologic change. Gastroenterology $80: 442$

35. Howdle PD, Corazza GR, Bullen AW, Losowsky MS 1979 In vitro demonstration of mucosal sensitivity to gluten. Gut 20:436

36. Jos J, Charbonnier L, Mougenot JF, Mosse J, Rey J 1978 Isolation and characterization of the toxic fraction of wheat gliadin in coeliac disease. In: McNicholl BM. McCarthy CF, Fottrell PF (eds) Perspectives in Coeliac Disease. MTP Press Limited, Lancaster, p 75

37. Jos J, Charbonnier L, Mosse J, Olives JP, De Tand MF, Rey J 1982 The toxic fractionation of gliadin digest in coeliac disease. Isolation by chromatography on Biogel-10. Clin Chim Acta 119:263

38. Jos J, De Tand MF. Charbonnier L 1980 Use of gel filtration to isolate the toxic fraction of gliadin digest in coeliac disease. Acta Paediatr Bel 33:269

39. Jos J, Lenoir G, de Ritis G. Rey J 1974 In vitro culturing of biopsies from children. In: Hekkens WTJM, Pena AS (eds) Coeliac Disease. Stenfert Kroese, Leiden, $\mathrm{p} 91$

40. Jos J. Lenoir G, de Ritis G. Rey J 1975 In vitro pathogenetic studies of coeliac disease. Effects of protein on coeliac intestinal biopsy specimens maintained in culture for 48 hours. Scand J Gastroenterol 10:121

41. Kasarda DD 1981 Toxic proteins and peptides in coeliac disease: relation to cereal genetics. In: Walker DN. Kretchmer N (eds) Food, Nutrition and Evolution. Masson Publishing, New York, p 201

42. Kendall MJ, Cox PS, Schneider R. Hawkins CF 1972 Gluten subfractions in coeliac disese. Lancet 2:1065

43. Kieffer M, Frazier PJ, Daniels NWR, Coombs RRA 1982 Wheat gliadin fractions and other cereal antigens reactive with antibodies in the sera of coeliac patients. Clin Exp Immunol 50:65

44. Kottgen E. Volk B, Kluge F. Gerok W 1982 Gluten, a lectin with oligomannosyl specificity and the causative agent of gluten-sensitive enteropathy. Biochem Biophys Res Commun 109:168

45. Levine RA. Briggs GW, Harding RS, Nolte LB 1966 Prolonged gluten administration in normal subjects. N Engl J Med 274:1109

46. McNeish AS, Rolles CJ, Arthur LJH 1976 Criteria for diagnosis of temporary gluten intolerance. Arch Dis Child 51:275

47. Moulton ACL 1958 The place of oats in the coeliac diet Arch Dis Child 34.51

48. Nussle D. Bozic C, Cox J. Deleze G. Roulet M. Fete R, Megevand A 1978 Non-cocliac gluten intolerance in infancy. In: McNicholl B, McCarthy CF. Fottrell PF (eds) Perspectives in Coeliac Disease. MTP Press Limited, Lancaster, $\mathrm{p} 227$

49. Platt SG. Kasarda DD, Qualset CO 1974 Varietal relationships of the $\alpha$-gliadin proteins in wheat. J Sci Food Agric 25:155

50. Rocca E. Paganuzzi-Stammati A. Zampaglioni F. Zucco F 1984 Effects of gliadin-derived peptides from bre'sd and durum wheats on in vitro cultures of human cells lines: implications for coeliac disease pathogenesis. Toxicol Lett in press

51. Ross ACA. Frazer AC. French JM. Gerrard JW, Sammons HG, Smellie JM 1955 Coeliac disease. The relative importance of wheat gluten. Lancet 1:1087

52. Rubin CE. Brandborg LL. Flick AL. MacDonald WC, Parmentier CM, Phelps P. Sribhibhah S. Trier JS 1962 Biopsy studies on the pathogenesis of coeliac sprue. In: Wolstenholme GEW (ed) Intestinal Biopsy. Ciba Foundation Study Group No. 14. Ciba Drug Co. p 67

53. Rubin CE, Brandborg LL, Flick AL, Parmentier C, Phelps P, van Niel S 1960 The effect of wheat instillation into the proximal ileum of patients with idiopathic sprue. J Clin Invest 39:1023

54. Rubin CE, Brandborg LL, Flick AL, Phelps P, Parmentier C, van Niel S 1962 Studies on coeliac sprue. III. The effect of repeated wheat instillation into the proximal ileum of patients on a gluten-free diet. Gastroenterology 43:621

55. Rudman D. Yalambos JT, Wenger J, Achord J 1971 Adverse effects of dietary gluten in four patients with regional enteritis. Am J Clin Nutr 24:1068

56. Schenk EA. Samloff IM 1968 Clinical and morphological changes following gluten administration to patients with treated celiac disease. Am J Pathol 3:579

57. Schneider R. Bishop H. Shaw B. Frazer AC 1960 Effect of wheat gluten on the peristaltic reflex. Nature 187:516

58. Sheldon W 1955 Coeliac disease. Lancet 2:1097

59. Sheldon W, Lawson D 1952 The management of coeliac disease. Lancet 2:902

60. Shmerling DH, Shiner M 1970 The response of the intestinal mucosa to the intraduodenal instillation of gluten in patients with coeliac disease during remission. In: Booth CC. Dowling RH (eds) Coeliac Disease. Churchill Livingstone, London, p 64

61. Silano V, Auricchio S, de Ritis G, de Vincenzi M, Occorsio P 1981 Effects of gliadin-derived peptides from bread and durum wheat on small intestine cultures from rat fetus and coeliac children. In: Neubert D, Merker HJ (eds) Culture Techniques. Walter de Gruyter Co, Berlin, $\mathrm{p} 385$

62. Silano V, Bansul HC. Bozzini A 1981 Improvement of nutritional quality of food crops. FAO Plant Production Protection Paper 34:1

63. Ströber W 1978 An immunological theory of gluten sensitive enteropathy. In: McNicholl BM. McCarthy CF. Fottrell PF (eds) Perspectives in Coeliac Disease. MPT Press Limited, Lancaster, p 169

64. Van de Kamer JH. Dicke WM. Weijers HA 1953 Presence in wheat of a factor having a deleterious effect in cases of coeliac disease. Acta Paediatr 42:34

65. Van De Kamer JH, Weijers HA. Dicke WK 1953 Investigation into the injurious constituents of wheat in connection with their action on patients with coeliac disease. Acta Paediatr 42:223

66. Weijers HA, Van de Kamer $\mathrm{JH} 1960$ Some biochemical investigations into the cause of wheat sensitivity in coeliac disease. Gastroenterology 38:587

67. Weijers HA, Van de Kamer JH 1955 Experiments on cause of harmful effect of wheat gliadin. Acta Paediatr 44:465

68. Weiser MM. Douglas AP 1976 An alternative mechanism for gluten toxicity in coeliac disease. Lancet 1:567 